\title{
Humic Acid Removal from Aqueous Environments by Electrocoagulation Process Using Iron Electrodes
}

\author{
EDRIS BAZRAFSHAN ${ }^{1}$, HAMED BIGLARI ${ }^{1}$, AND AMIR HOSSEIN MAHVI $^{2,3,4^{*}}$ \\ ${ }^{1}$ Health Promotion Research Center, Zahedan University of Medical Sciences, Zahedan, Iran \\ ${ }^{2}$ School of Public Health, Tehran University of Medical Sciences, Tehran, Iran \\ ${ }^{3}$ Center for Solid Waste Research, Institute for Environmental Research, Tehran University \\ of Medical Sciences, Tehran, Iran \\ ${ }^{4}$ National Institute of Health Research, Tehran University of Medical Sciences, \\ Tehran, Iran \\ ahmahvi@yahoo.com
}

Received 16 August 2011; Accepted 04 October 2011

\begin{abstract}
At present study the performance of electrocoagulation process using iron electrodes sacrificial anode has been investigated for removal of HA from artificial aqueous solution. The experiments were performed in a bipolar batch reactor with four iron electrode connected in parallel. Several working parameters, such as initial $\mathrm{pH}(3,5,7$, and 9), electrical conductivity (50 V) and reaction time were studied in an attempt to achieve the highest removal capacity. Solutions of HA with concentration equal $20 \mathrm{mg} \mathrm{L}^{-1}$ were prepared. To follow the progress of the treatment, samples of $10 \mathrm{ml}$ were taken at 15,30 , 45,60 , and $75 \mathrm{~min}$ interval. Finally HA concentration was measured by UV absorbance at $254 \mathrm{~nm}\left(\mathrm{UV}_{254}\right)$ and TOC concentration was measured by TOC Analyser. The maximum efficiency of HA removal which was obtained in voltage of $50 \mathrm{~V}$, reaction time of $75 \mathrm{~min}$, initial concentration $20 \mathrm{mg} \mathrm{L}^{-1}$, conductivity $3000 \mu \mathrm{S} / \mathrm{Cm}$ and $\mathrm{pH} 5$, is equal to $92.69 \%$. But for natural water samples at the same optimum condition removal efficiency was low $(68.8 \%)$. It can be concluded that the electrocoagulation process has the potential to be utilized for cost-effective removal of HA from aqueous environments.
\end{abstract}

Keywords: Humic acid, Electrocoagulation, Iron Electrodes, Aqueous environments.

\section{Introduction}

Organic matter in the environment can be divided in two main classes of compounds, nonhumic material, such as proteins, polysaccharides, nucleic acids, etc. and humic substances ${ }^{1}$. Humic acids (HA) are one of the major components of humic substances which arise by the microbial degradation of biomolecules. They may account for up to $90 \%$ of $\mathrm{NOM}^{2}$. The presence of humic substances in surface and ground waters, pose a variety of problems in treatment operations and distribution systems. For example its presence in water introduces taste, odor, and a yellowish to brown color ${ }^{3}$. Moreover, high affinity of humic substances (Figure 1) for complexation with various pollutants including heavy metals causes 
contamination of ground and surface water ${ }^{4,5}$. In addition, HA will form very toxic disinfection byproducts (DBPs); i.e. chlorinated organic compounds, for example, trihalomethanes (THMs), which exhibit mutagenic properties during chlorination step in tap or drinking water production or water treatment ${ }^{4,6}$. The guideline values for DBPs in drinking water announced by the World Health Organization should not exceed $100 \mu \mathrm{g} \mathrm{L}^{-1} 7$. Consequently, removal of HA from surface water or wastewater is important and considered of great health and environmental concern. This is usually accomplished by coagulation and precipitation, i.e., adding salts of hydrolysed metals, such as aluminium sulfate and organic polymers, followed by gravity sedimentation or filtration ${ }^{8-10}$. Other treatment techniques, which have been examined for the removal of HA, are ion exchange ${ }^{11}$, sorption ${ }^{6}$, membrane processes, such as reverse osmosis and ultrafiltration ${ }^{12}$, flotation ${ }^{13}$, bioflocculation ${ }^{1}$, and chemical oxidation such as ozonation ${ }^{2}$ and Fenton process ${ }^{3}$.

Electrocoagulation process is an alternative of the conventional coagulation process in which coagulant agents are generated in situ through the dissolution of a sacrificial anode by applying current between the anode-cathode electrodes. The electrocoagulation process has several advantages that make it attractive for treating various contaminated streams. In the past decades electrocoagulation has been applied for the treatment of many kinds of wastewater such as landfill leachate, restaurant wastewater, textile wastewater, petroleum refinery wastewater, tannery wastewater, laundry wastewater, and for removal of fluoride, pesticides and heavy metals from aqueous environments ${ }^{14-21}$.

An examination of the chemical reactions occurring in the electrocoagulation process shows that the main reactions occurring at the iron electrodes are:

$$
\begin{gathered}
\mathrm{Fe}(\mathrm{s}) \longleftrightarrow \mathrm{Fe}^{+3}{ }_{\text {aq }}+3 \mathrm{e}^{-} \quad \text { (anode) } \\
3 \mathrm{H}_{2} \mathrm{O}+3 \mathrm{e}^{-} \longmapsto 3 / 2 \mathrm{H}_{2 \mathrm{~g}}+3 \mathrm{OH}_{\text {aq }}^{-} \text {(cathode) }
\end{gathered}
$$

In addition, $\mathrm{Fe}^{3+}$ and $\mathrm{OH}^{-}$ions generated at electrode surfaces react in the bulk wastewater to form ferric hydroxide:

$$
\mathrm{Fe}^{+3}{ }_{\mathrm{aq}}+3 \mathrm{OH}_{\mathrm{aq}}^{-} \longmapsto \mathrm{Fe}(\mathrm{OH})_{3}
$$

The iron hydroxide flocs formed remains in the aqueous stream as a gelatinous suspension and act as adsorbents and/or traps for pollutants and so eliminate them from the solution $^{22,23}$. The main purpose of this work is to study of the electrocoagulation process efficiency for HA removal from aqueous environments with iron electrodes and determination of the effects of $\mathrm{pH}$, electrical conductivity and reaction time on the removal efficiency.

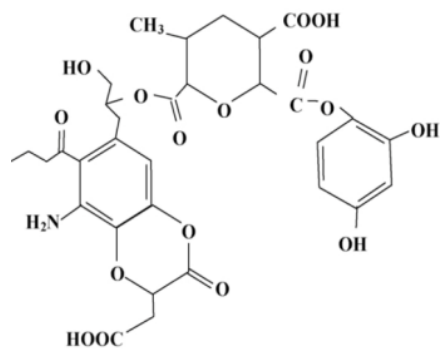

Figure 1. The chemical structure of humic acid. 


\section{Experimental}

At present study all chemicals were of standard analytical grade and used without further purification unless otherwise noted. A stock solution of $\mathrm{HA}$ at $1 \mathrm{~g} \mathrm{~L}^{-1}$ is prepared by dissolving $1 \mathrm{~g}$ of $\mathrm{HA}$ in $62.5 \mathrm{~mL}$ of $\mathrm{NaOH}(2 \mathrm{~N})$ solution, as $\mathrm{HA}$ dissolves well under alkaline conditions, and then completed to $1 \mathrm{~L}$ with distilled water (with $10 \mu \mathrm{S} \mathrm{cm}^{-1}$ at $25^{\circ} \mathrm{C}$ as conductivity) in a $1 \mathrm{~L}$ vial. This solution is submitted to magnetic agitation during $48 \mathrm{~h}$ and then conserved at $4^{\circ} \mathrm{C}$ in the absence of light. Working solutions (HA solutions, $20 \mathrm{mg}$ $\mathrm{L}^{-1}$ ) were prepared by dilution of stock solution in de-ionized water.

\section{Set-up and Procedure}

Experiments were performed in a bipolar batch reactor, with four iron electrode connected in parallel. The internal size of the cell was $10 \mathrm{~cm} \times 13 \mathrm{~cm} \times 12 \mathrm{~cm}$ (width $\times$ length $\times$ depth) with an effective volume of $1000 \mathrm{Cm}^{3}$. The volume $(\mathrm{V})$ of the solution of each batch reactor was $1 \mathrm{~L}$. The active area of each electrode (plate) was $10 \times 10 \mathrm{~cm}$ with a total area of $400 \mathrm{Cm}^{2}$. The distance between electrodes was $2 \mathrm{~cm}$. A power supply pack having an input of $220 \mathrm{~V}$ and variable output of $0-60 \mathrm{~V}$ ( $50 \mathrm{~V}$ for this study) with maximum electrical current of 5 ampere was used as direct current source. The temperature of each system was maintained at $25 \pm 1^{0} \mathrm{C}$.

After the introduction of HA solution to treat in the electrocoagulation reactor (Figure 2), the $\mathrm{pH}$ is adjusted at its selected initial value $(3,5,7$, and 9) using $\mathrm{HCl}$ and $\mathrm{NaOH}$ solutions $(0.1 \mathrm{~N})$ and also the electrical conductivity is adjusted at its selected initial value (1000, 1500,2000 and $\left.3000 \mu \mathrm{S} \mathrm{cm}^{-1}\right)$ using $\mathrm{KCl}$ solution $(0.1 \mathrm{~N})$. The chloride salt added to the solution can also prevent the formation of the oxide layer on the anode and therefore reduce the passivation problem of the electrodes. The $\mathrm{pH}$ values in influent and reactor unit were measured using a pH meter model E520 (Metrohm Herisau, Switzerland). A Jenway Conductivity Meter (Model 4200) was employed to determine the conductivity of the solution. Samples were taken for analysis every $15 \mathrm{~min}$ (up to $75 \mathrm{~min}$ ) from the solution by pipetting.

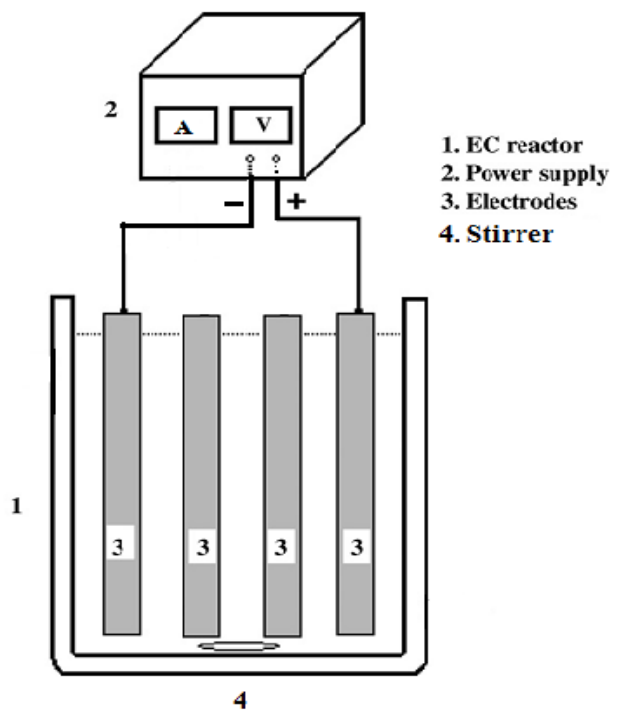

Figure 2. The schematic view of electrochemical reactor. 
Ultraviolet (UV) absorption spectroscopy and total organic carbon (TOC) were used for HA measurement. In the UV method, the samples were placed in a $4 \mathrm{~mL}$ quartz cuvette and UV absorbance values of the samples were measured at a wavelength of $254 \mathrm{~nm}$. A standard calibration curve of $\mathrm{UV}_{254}$ absorbance against $\mathrm{HA}$ concentration $\left(0.1-30 \mathrm{mg} \mathrm{L}^{-1}\right)$ was produced, from which the concentration of unknown sample can be obtained. Also, the total organic carbon of samples was measured using a TOC Analyser (ANATOC Series II). The analyser was first calibrated and a standard curve was produced by varying the concentration of HA. Samples were placed in $40 \mathrm{~mL}$ glass vials, placed in a circular holder of the machine. The sample collection and measurements were done automatically. During the runs, the reactor unit was stirred at $70 \mathrm{rpm}$ by a magnetic stirrer to allow the chemical precipitate to grow large enough for removal. During electrocoagulation, an oxide film formed at the anode. In order to overcome electrode passivation at the anode, the electrodes were rinsed in diluted $\mathrm{HCl}$ solution $(5 \% \mathrm{v} / \mathrm{v})$ after each experiment and rinsed again with tap water and finally weighted. All analyses were conducted in duplicate for reproducibility of data, and all of the data in the Figures and Tables were the average ones.

\section{Results and Discussion}

The electrocoagulation process is quite complex and may be affected by several operating parameters, such as pollutants concentrations, initial $\mathrm{pH}$, applied voltage, electrical conductivity, and reaction time. In the present study, electrocoagulation process has been evaluated as a treatment technology for HA removal from synthetic solutions. HA removal efficiency at different condition ( $\mathrm{pH}$, conductivity and reaction time) was evaluated.

\section{Effect of Initial $p H$}

It has been established that the $\mathrm{pH}$ has a considerable influence on the performance of electrocoagulation process ${ }^{24-27}$. Therefore, $\mathrm{pH}(3,5,7$ and 9) was examined as one of the main variables affecting electrocoagulation removal of HA from synthetic solutions. The results are shown in Figure 3, from which the variation of removal efficiency of HA with the solution initial $\mathrm{pH}$ could be clearly identified. The optimal $\mathrm{pH}$ was 5 (removal efficiency $\sim 92.69 \%$ ), at which higher HA removal efficiency could be reached. The average HA removal for a conductivity value of $53000 \mu \mathrm{S} / \mathrm{cm}$ increased from $87.45 \%$ to $92.69 \%$ when the $\mathrm{pH}$ was increased from 3 to 5. Further increasing the $\mathrm{pH}$ to 7 and 9 resulted in a reduction of HA removal efficiency to $80.12 \%$ and $71.9 \%$, respectively. This result support that electrocoagulation process efficiency is a function of initial $\mathrm{pH}$. On the other hand, the results indicate that the reaction performance is dependent on initial $\mathrm{pH}$ values, where the lower $\mathrm{pH}$ values lead to faster reactions and better efficiency. This result is in agreement with results obtained by other researchers ${ }^{28}$.

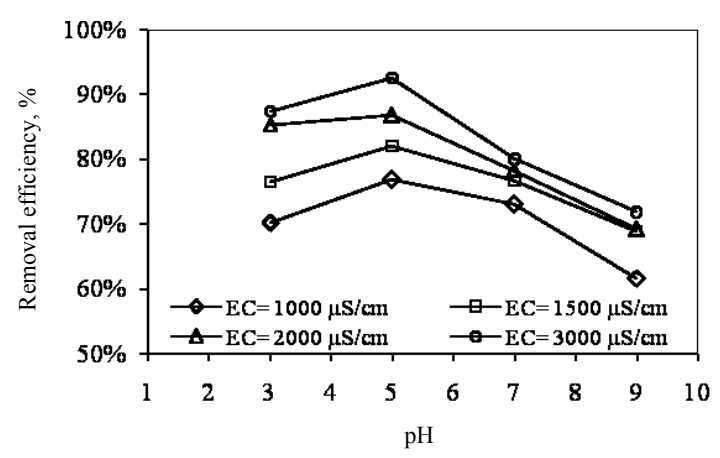

Figure 3. Effect of $\mathrm{pH}$ on the removal efficiency of HA (initial concentration of HA: $20 \mathrm{mg} \mathrm{L}^{-1}$, applied voltage: $50 \mathrm{~V}$ and reaction time: $75 \mathrm{~min}$ ). 
Theoretically, $\mathrm{pH}$ values of the solution affect the appearance of HA directly. An aromatic ring is the basic unit of HA (Figure 1); it is a reticular macromolecule polymer connected by hydrogen bonds between functional retentions. The most active functional retentions are carboxyl and phenolic hydroxyl groups. As a consequence dissociation of $\mathrm{H}^{+}$ form carboxyl or hydroxyl relates to the $\mathrm{pH}$ value of the solution. When the $\mathrm{pH}$ value is lower, carboxyl and hydroxyl radicals exist in the chemical form of $-\mathrm{COOH}$ and $-\mathrm{OH}$ respectively. When $\mathrm{pH}$ values are higher, they exist in the form of $-\mathrm{COO}^{-}$and $-\mathrm{O}^{-}$. It's clearly that under conditions of a higher $\mathrm{pH}$, HA takes on a more negative charge and more $\mathrm{Fe}^{3+}$ is consumed to neutralize the negative charge. Therefore, the removal efficiency will decrease under higher $\mathrm{pH}$ values.

Furthermore, as shown in Figure 4, the $\mathrm{pH}$ of the solution changes during the process. The $\mathrm{pH}$ variation of the solution after electrocoagulation process (Figure 4) showed that the final $\mathrm{pH}$ for all of the experiments with iron plate electrodes is higher compared to the initial $\mathrm{pH}$, which is in agreement with results obtained by other researchers ${ }^{18,29,30}$.

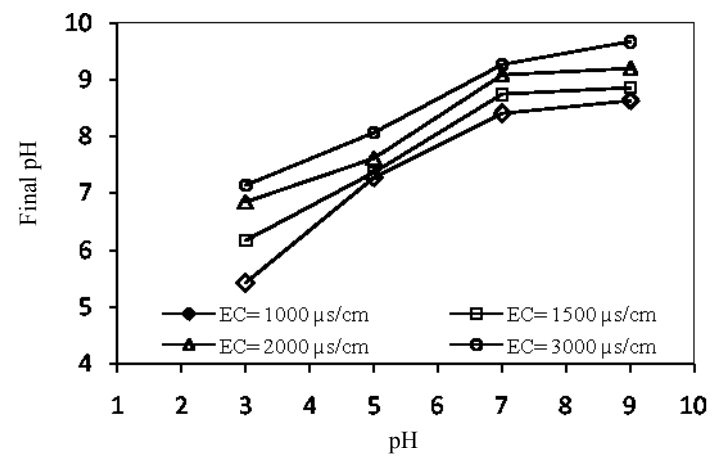

Figure 4. Variation of initial $\mathrm{pH}$ during electrocoagulation process (initial concentration of $\mathrm{HA}: 20 \mathrm{mg} \mathrm{L}^{-1}$, applied voltage: $50 \mathrm{~V}$ and reaction time: $75 \mathrm{~min}$ ).

It has been shown that variation of energy consumption with initial $\mathrm{pH}$ of the water as a function of time in Figure 5. When examining Figure 5, it can be seen that energy consumptions have generally minimum values, when initial $\mathrm{pH}$ and conductivity equals 5 and $1000 \mu \mathrm{S} / \mathrm{cm}$, respectively and it is maximum for other initial $\mathrm{pH}$ and conductivity values. On the other hand, when the initial $\mathrm{pH}$ increased from 3 to 5 (at conductivity: $3000 \mu \mathrm{S} / \mathrm{cm}$ ), the HA removal efficiency increased appreciably, from $87.45 \%$ to $92.69 \%$, whereas the corresponding specific energy consumption increased only slightly. Therefore, in present study, initial $\mathrm{pH} 5$ is chosen as optimum $\mathrm{pH}$ for electrocoagulation process.

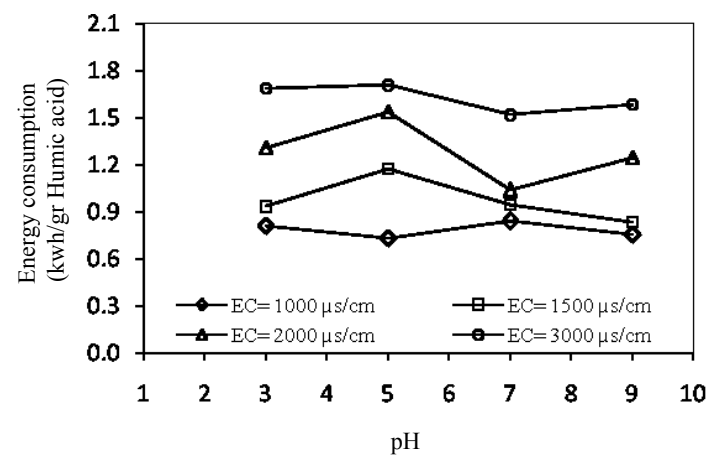

Figure 5. Variation of energy consumption as a function of initial $\mathrm{pH}$ and conductivity (initial concentration of HA: $20 \mathrm{mg} \mathrm{L}^{-1}$, applied voltage: $50 \mathrm{~V}$ and reaction time: $75 \mathrm{~min}$ ). 


\section{Effect of Reaction Time}

In accordance with Faraday Act, the time of electrolysis in electrocoagulation process affects the rate of metal ion released into the system ${ }^{31}$, so, the removal efficiency of HA in the electrocoagulation cell was evaluated as a function of the reaction time.

HA removal efficiencies as a function of electrocoagulation time at constant electrolysis voltage $(50 \mathrm{~V})$ are shown in Figure 6 . At the beginning of the reaction, the removal efficiency of HA obviously changed with the reaction time. As shown in Figure 6 and 7, HA removal increased with increasing reaction time and most of the reduction in HA was achieved within the first $15 \mathrm{~min}$ of the reaction and was approximately $52.1 \%$ at conductivity $3000 \mu \mathrm{S} / \mathrm{cm}$. A further increase in reaction time to $75 \mathrm{~min}$ resulted in an improved HA removal of approximately $92.69 \%$ (HA concentration $<1.46 \mathrm{mg} \mathrm{L}^{-1}$ ). The same trend of evolution of removal efficiency with electrocoagulation time was reported by other researchers ${ }^{15,16,28,32,33}$. The process can be divided into two steps: a primary rapid step and a secondary slow step, resembling the adsorption rate of $\mathrm{Pb}^{2+}$ ions onto the microparticles in a previous study by Huang et $a l .{ }^{34}$.

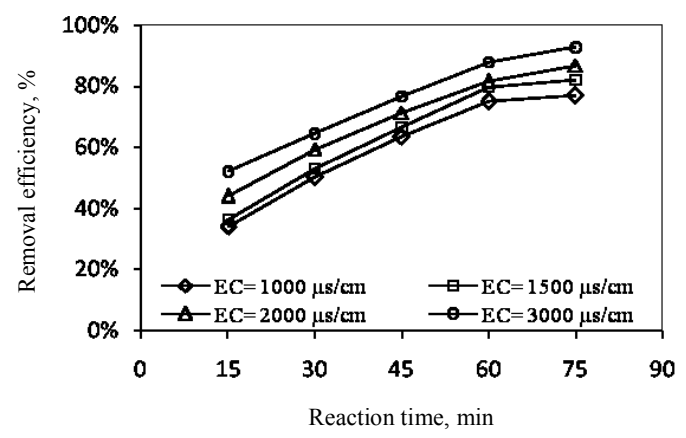

Figure 6. Effect of reaction time on the HA removal efficiency as a function of conductivity (initial concentration of HA: $20 \mathrm{mg} \mathrm{L}^{-1}, \mathrm{pH}$ : 5, applied voltage: $50 \mathrm{~V}$ ).

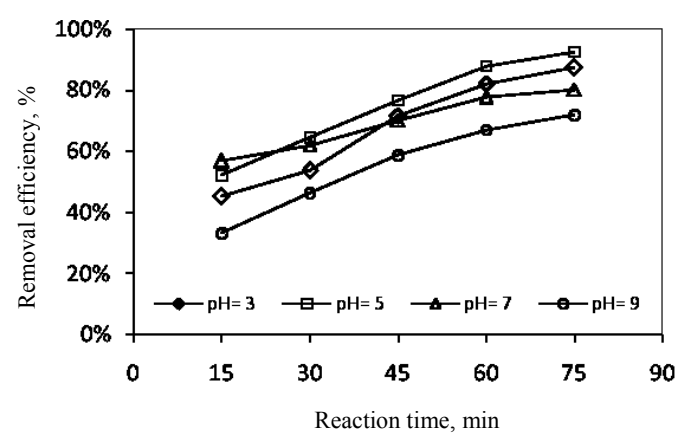

Figure 7. Effect of reaction time on the HA removal efficiency as a function of $\mathrm{pH}$ (initial concentration of HA: $20 \mathrm{mg} \mathrm{L}^{-1}$, conductivity: $3000 \mu \mathrm{S} / \mathrm{cm}$, applied voltage: $50 \mathrm{~V}$ ).

\section{Effect of Electrical Conductivity}

A set of experiments was performed to determine the effect of electrical conductivity of solution on HA removal efficiency as a function of $\mathrm{pH}$ and reaction time. These experiments 
were performed using $\mathrm{KCl}$ as the electrolyte in the range of $1000-3000 \mu \mathrm{S} / \mathrm{cm}$ at applied voltage of $50 \mathrm{~V}$, initial HA concentration equal $20 \mathrm{mg} \mathrm{L}^{-1}$ and $\mathrm{pH}$ range 3-9.

The results obtained at different electrical conductivity values (Figure 8 and 9) showed that conductivity of solution has a considerable influence on the performance of electrocoagulation process, which is in agreement with results obtained by Gulsun Kilic and Hosten $^{35}$. As the solution conductivity increased from $1000 \mu \mathrm{S} / \mathrm{cm}$ to $3000 \mu \mathrm{S} / \mathrm{cm}$, the HA removal efficiency increased from 76.95 to $92.69 \%$ for the $\mathrm{pH}$ 5. The residual HA concentration was $1.46 \mathrm{mg} \mathrm{L}^{-1}$ after $75 \mathrm{~min}$ of electrocoagulation at conductivity of 3000 $\mu \mathrm{S} / \mathrm{cm}$. When the conductivity of the solution increased, the current flow during electrocoagulation increased; as a result, the efficiency of HA removal was enhanced. Golder et al. reported that the availability of metal coagulants increases with increasing conductivity ${ }^{36}$.

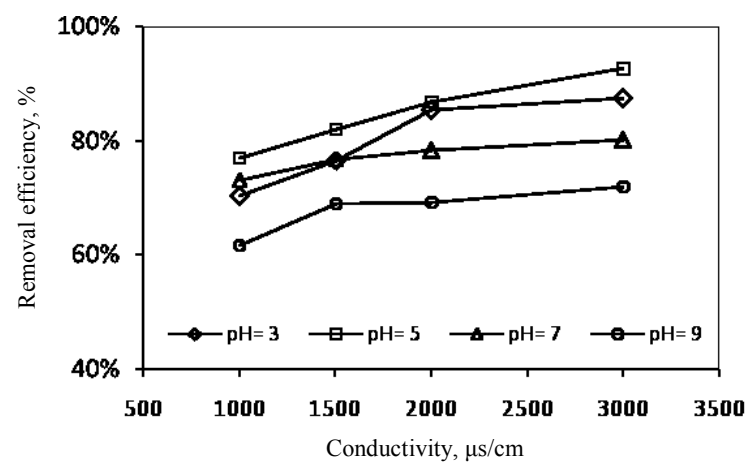

Figure 8. Effect of conductivity on the HA removal efficiency as a function of $\mathrm{pH}$ (initial concentration of HA: $20 \mathrm{mg} \mathrm{L}^{-1}$, reaction time: $75 \mathrm{~min}$, applied voltage: $50 \mathrm{~V}$ ).

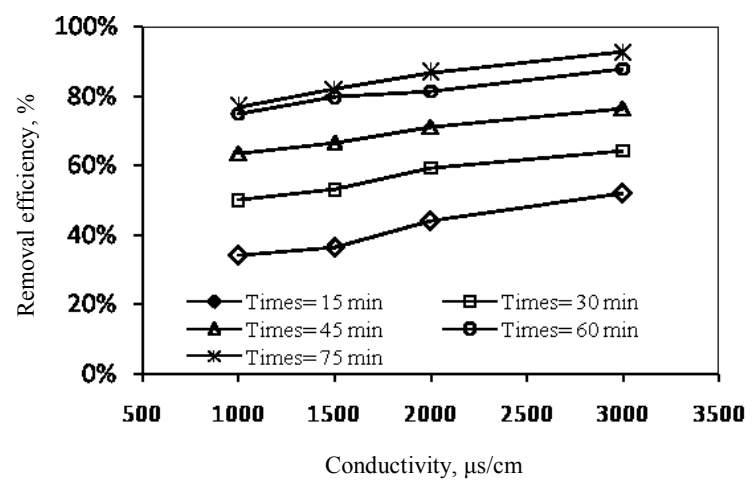

Figure 9. Effect of conductivity on the HA removal efficiency as a function of reaction time (initial concentration of HA: $20 \mathrm{mg} \mathrm{L}^{-1}, \mathrm{pH}$ : 5, applied voltage: $50 \mathrm{~V}$ ).

In previous studies, Chen et al. found that conductivity had little effect on the separation of pollutants from restaurant wastewater in the investigated range from $443 \mu \mathrm{S} / \mathrm{cm}$ to $2850 \mu \mathrm{S} / \mathrm{cm}^{17}$. Kobya et al. studied the effect of wastewater conductivity on the performance of the electrocoagulation process using aluminum and iron electrodes ${ }^{18}$. They found that the turbidity removal efficiency remained almost unchanged in the conductivity range of 1000$4000 \mu \mathrm{S} / \mathrm{cm}$ for both electrode materials. But, it was in contrast to that given by Lin and Peng for electrocoagulation of textile wastewater using iron electrodes ${ }^{37}$. 
Increasing solution conductivity resulted in the reduction of cell voltages that caused a decrease in electrical energy consumption ${ }^{38}$. But our findings showed (Figure 10) that at constant voltage, increasing of solution conductivity resulted in the increase of electrical energy and electrode consumption.

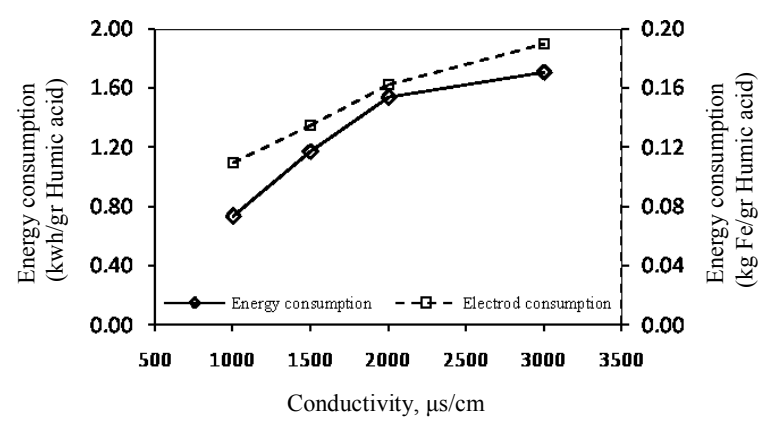

Figure 10. Effect of conductivity on the electrical energy and electrode consumption (initial concentration of HA: $20 \mathrm{mg} \mathrm{L}^{-1}, \mathrm{pH}$ : 5 , applied voltage: $50 \mathrm{~V}$, reaction time: $75 \mathrm{~min}$ ).

It can be seen from Figure 10 that electrical energy and electrode consumption were found to increase with increasing the conductivity of solution. An increase in conductivity from 1000 to $3000 \mu \mathrm{S} / \mathrm{cm}$ causes an increase in energy consumption from 0.735 to 1.71 $\mathrm{kWh} \mathrm{g}^{-1}$. Also, an increase in conductivity from 1000 to $3000 \mu \mathrm{S} / \mathrm{cm}$ causes an increase in electrode consumption from 0.11 to $0.19 \mathrm{~kg} \mathrm{~g}^{-1}$ of HA.

When the conductivity was increased from 1000 to $3000 \mu \mathrm{S} / \mathrm{cm}$, the HA removal efficiency increased appreciably, from $76.95 \%$ to $92.69 \%$ for $\mathrm{pH} 5$, whereas the corresponding specific energy and electrode consumption increased only slightly. Therefore, in present study, $3000 \mu \mathrm{S} / \mathrm{cm}$ is chosen as optimum conductivity for electrocoagulation process.

\section{Conclusion}

The present study attempted to investigate the applicability of an electrocoagulation method using $\mathrm{Fe}$ electrodes in the removal of HA from aqueous environments. The influence of various variables such as $\mathrm{pH}$, reaction time, and conductivity of solution on the removal of HA was investigated. The results showed that electrocoagulation process with Fe electrode could successfully remove HA from the aqueous environments. The results obtained with synthetic solutions revealed that the most effective removal capacities of HA achieved at $\mathrm{pH}$ 5. In addition, the increase of reaction time, in the range of 15-75 min, enhanced the treatment rate. The maximum efficiency of HA removal which was obtained in constant electrolysis voltage of $50 \mathrm{~V}$, reaction time of $75 \mathrm{~min}$, initial concentration $20 \mathrm{mg} \mathrm{L}^{-1}$, conductivity $3000 \mu \mathrm{S} / \mathrm{Cm}$ and $\mathrm{pH} 5$ is equal to $92.67 \%$. Also the results showed that at constant voltage, increasing of solution conductivity resulted in the increase of electrical energy and electrode consumption. Finally, the results show that electrocoagulation process can effectively reduce HA contaminant to a very low level.

\section{Acknowledgment}

This study was funded by the health research deputy of Zahedan University of Medical Sciences and was conducted in the Chemical Laboratory of School of Public Health, Zahedan University of Medical Sciences. 


\section{References}

1. Zouboulis A I, Chai X L and Katsoyiannis I A, J Environ Manag., 2004, 70, 35.

2. Seredynska S B, Tomaszewska M and Morawski A W, Desalination, 2006, 198, 265.

3. Wu Y, Zhoua Sh, Ye X, Zhao R and Chen D, Colloids Surfaces A: Physicochem Eng Aspects., 2011, 379, 151.

4. Ghernaout D, Ghernaout B, Saiba A, Boucherit A and Kellil A, Desalination, 2009, 239, 295.

5. Camper A K, Intern J Food Micro., 2004, 92, 355.

6. Imyim A and Prapalimrungsi E, J Hazard Mater., 2010, 184, 775.

7. World Health Organization, Guidelines for Drinking-water Quality, third Ed., World Health Organization, Geneva, 2008.

8. Chow Ch W, Leeuwen J A, Fabris R and Drikas M, Desalination, 2009, 245, 120.

9. Park S J and Yoon T I, Desalination, 2009, 239, 146.

10. Yan M, Liu H, Wang D, Ni J and Qu J, Water Science \& Technology: Water SupplyWSTWS, 2009, 9, 1.

11. Brattebo H, Odegaard H and Halle O, Water Res., 1987, 21(9), 1045.

12. Lowe J and Hossain Md M, Desalination, 2008, 218, 343.

13. Zouboulis A I, Jun W and Katsoyiannis I A, Colloids Surfaces A: Physicochem Eng Aspects., 2003, 231, 181.

14. Ilhan F, Kurt U, Apaydin O and Gonullu M T, J Hazard Mater., 2008, 154, 381.

15. Bazrafshan E, Mahvi A H, Nasseri S and Shaighi M, Iran J Environ Health Sci Eng., 2007, 2(4), 127.

16. Bazrafshan E, Mahvi A H, Naseri S and Mesdaghinia A R, Turkish J Eng Environ Sci., 2008, 32(2), 59.

17. Chen X, Chen G and Po L Y, Sep Purif Technol., 2000, 9, 65.

18. Kobya M, Taner Can O and Bayramoglu M, J Hazardous Mater., 2003, B100, 163.

19. Yao Hua Ch, Lien Loa Sh, Kuan W H and Lee Y D, Separ Purif Technol., 2008, 60, 1.

20. El-Naas M H, Al-Zuhair S, Al-Lobaney A and Makhlouf S, J Environ Manag., 2009, 91, 180.

21. Şengil I A, Kulac S and Ozacar M, J Hazard Mater., 2009, 167, 940.

22. Cenkin V E and Belevstev A N, Eff Water Treat J., 1985, 25(7), 243.

23. Mollah M, Schennach R, Parga J R and Cocke DL, J Hazard Mater., 2001, B84, 29.

24. Chen G, Sep Purif Technol., 2004, 38, 11.

25. Gao P, Chen X and Shen F, Sep Purfi Technol., 2005, 43(2), 117.

26. Nouri J, Mahvi A H and Bazrafshan E, J Environ Res., 1010, 4(2), 201.

27. Irdemez S, Demircio ־glu N and Yildiz Y S, J Hazard Mater., 2006, 137(2), 1231.

28. Qi-yan F, Xiang-dong L, Yu-jie Ch, Lei M and Qing-jun M, J China Univ Mining \& Technol., 2007, 17(4), 0513.

29. Katal R and Pahlavanzadeh H, Desalination, 2011, 265, 199.

30. Bazrafshan E, Mahvi A H, Nasseri S, Mesdaghinia A R, Vaezi F and Nazmara Sh, Iran J Environ Health Sci Eng., 2006, 3(4), 261.

31. Emamjomeh M and Sivakumar M, J Environ Manage., 2009, 90, 1204.

32. Bayramoglu M, Kobya M, Can O T and Sozbir M, Sep Purfi Technol., 2004, 37, 117.

33. Drouiche N, Aoudj S, Hecini M, Ghaffour N, Lounici H and Mameri N, J Hazard. Mater., 2009, 169, 65.

34. Huang M R, Peng Q Y and Li X G, Chem Eur J., 2006, 12, 4341.

35. Gulsun K1lic M and Hosten Cetin A, J Hazard Mater., 2010, 176, 735.

36. Golder A K, Samanta A N and Ray S, J Hazard Mater., 2007, 141, 653.

37. $\quad$ Lin S H and Peng C F, Water Res., 1994, 28, 277.

38. Daneshvar N, Oladegaragoze A and Djafarzadeh N, J Hazard Mater., 2006, B129, 116. 


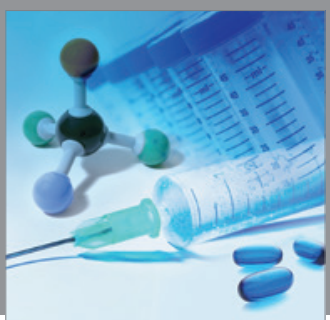

International Journal of

Medicinal Chemistry

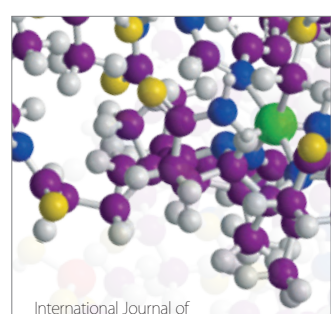

Carbohydrate Chemistry

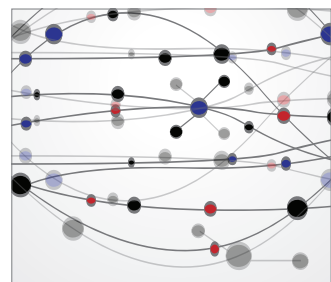

The Scientific World Journal
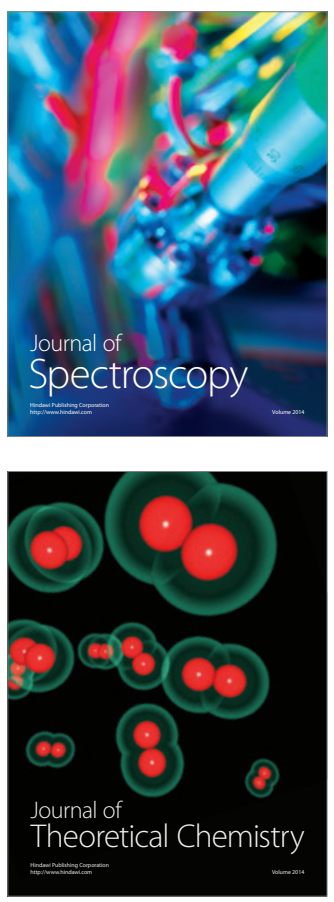
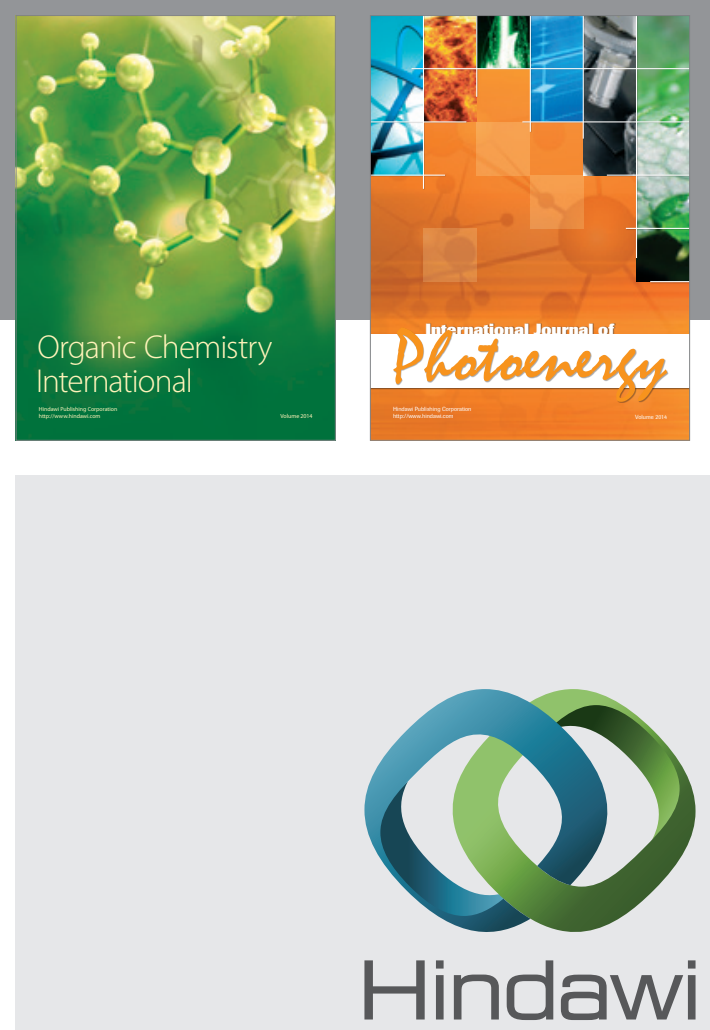

Submit your manuscripts at

http://www.hindawi.com
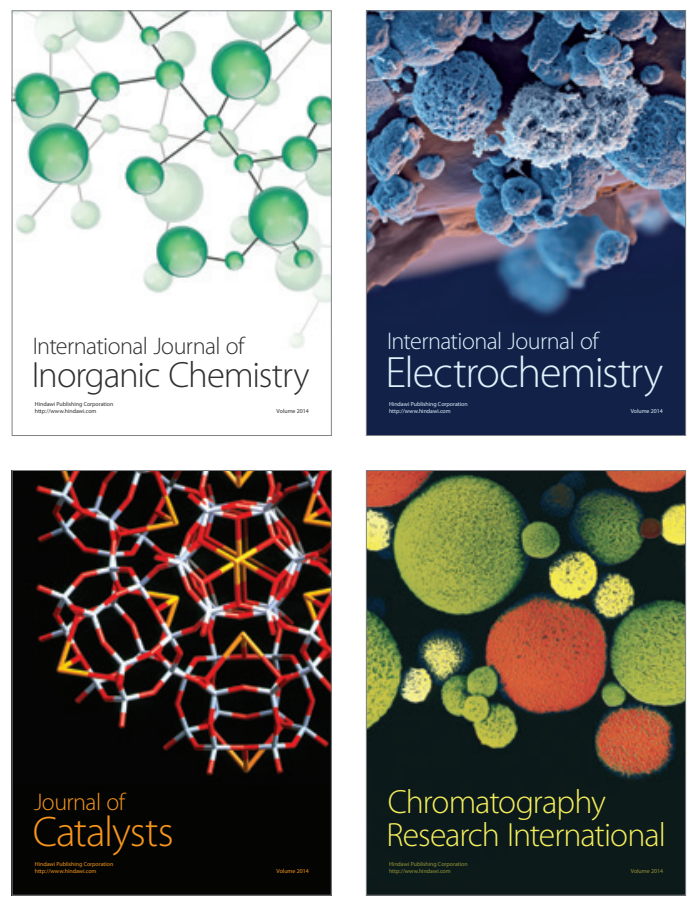
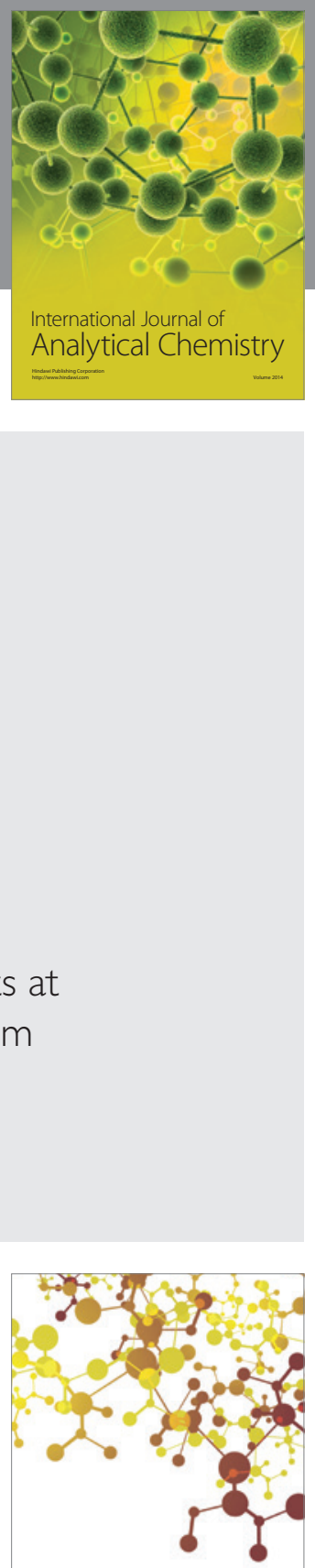

Journal of

Applied Chemistry
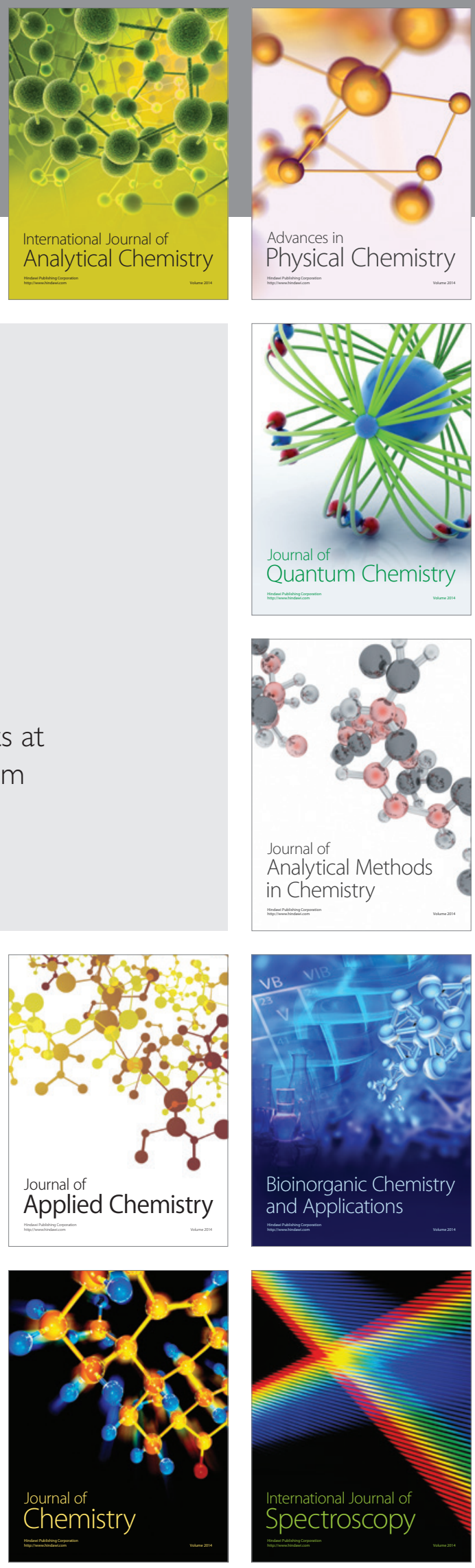